\title{
Purchasing power, fruits vegetables consumption, nutrition status among elementary school student
}

\author{
Yohan Fallo $^{1}$, Adi Magna Patriadi Nuhriwangsa ${ }^{2}$, Diffah Hanim ${ }^{3}$ \\ ${ }^{1}$ Human Nutrition, Nutrition Science, Master Program of Sebelas Maret, Indonesia \\ ${ }^{2}$ Department of Animal Science, UNS Faculty of Agriculture, Indonesia \\ ${ }^{3}$ Department of Nutrition, UNS Faculty of Medicine, Indonesia
}

\begin{tabular}{l} 
Article Info \\
\hline Article history: \\
Received Dec 28, 2018 \\
Revised Jan 24, 2019 \\
Accepted Feb 18, 2019 \\
\hline Keywords: \\
Fruits and vegetables \\
consumption, \\
Nutrition status, \\
Purchasing power,
\end{tabular}

Corresponding Author:

Yohan Fallo,

Human Nutrition, Nutrition Science,

Master Program of Sebelas Maret University, Surakarta,

J1 Ir Sutami No 36A, Jebres, Surakarta, Central Java 57126.

Email : johan21mu@gmail.com

\begin{abstract}
Food purchasing power is usually defined as a household's economic ability to obtain food which is determined by measuring the income allocated for food purchase, the price of food consumed, and the number of family members. More than $50 \%$ of the sub-districts in South Central Timor are vulnerable to food consumption due to their low purchasing power, thus causing low fruits and vegetables consumption. To analyze the correlation between purchasing power, fruits and vegetables consumption, with nutrition status of elementary school students. Analytic observational using a Cross sectional design. Sample size of 108 students was achieved using simple random sampling method. Independent variables are purchasing power, fruits and vegetables consumption. Dependent variable is nutrition status. Fruits and vegetables consumption data was collected using food frequency, purchasing power data was collected using questionnaires, and nutrition status was collected by calculating IMT/U. The statistics tests used were Chi square test. The mean number of fruits and vegetables consumption of the elementary students was $0.36 \pm 0.483$ and the mean number of purchasing power was $2.80 \pm 0.405$. Bivariate study test results show a significant correlation between purchasing power and nutrition status $(\mathrm{p}=0.039)$ and a significant correlation between fruits and vegetables consumption and nutrition status $(\mathrm{p}=0.000)$. There is a correlation between purchasing power, fruits and vegetables consumption, and nutrition status in elementary school students.
\end{abstract}

Copyright $\odot 2019$ Institute of Advanced Engineering and Science. All rights reserved.

\section{INTRODUCTION}

The national food organization defines food security as a situation where every people in every time have social and economic access to safe and nutritious food to fulfill their consumption needs. In developing countries, food security is in decreasing condition during the past years, especially due to the increase of population and the discrepancy between food supply and demand [1-2]. Economic growth quality influences public welfare. Economic growth is usually followed by the decrease of poverty and the increase of Human Development Index (HDI). Economic issues in a family will impact to the continuity of a child's education [3].

Food purchasing power is usually defined as a household's economic ability to obtain food which is determined by measuring the income allocated for food purchase, the price of food consumed, and the number of family members. Food purchasing power depends on the level of income and the price of food consumed [4]. Middle to lower class household has a tendency to be vulnerable to food consumption. 
Though economic factor is not the only contributing factor, it also can influence access to food. Parents' level of income will influence the ability of a household to access food [5].

According to Tiwari and Joshi [1], a country's economic condition will decrease due to an economic crisis, thus causing lack of food consumption. According to Center of food consumption diversification and security (RAD-PG) of East Nusa Tenggara Province in year 2015, South Central Timor District has 32 sub-districts and more than $50 \%$ of those sub-districts are vulnerable to food consumption, this phenomena caused by society's low purchasing power to food that led to low consumption level of vitamin sources, which are fruits and vegetables. Low income level causes an inability of a household to access various kinds of food, especially animal proteins, vitamins, and minerals sources [6]. Basic health research result in 2013 shows that nationally there are more than $90 \%$ of citizens aged $>10$ years old who don't consume enough fruits and vegetables [7]. Consuming fruits and vegetables is very important for children's health. In developed countries, it is recommended that children aged 9-13 years old need to consume a minimum of 1.5-3 cups of vegetables and 1.5-2 cups of fruits per day [8].

Besides that fact, the community generally has not placed food consumption as a priority. It is seen from the low proportion of a household's expense to animal products, fruits and vegetables consumption, meanwhile the expense for carbohydrate consumption is still predominant [9-10]. External factors that also influence fruits and vegetables consumption are the availability of fruits and vegetables, mother's (parents') education level, family income level, and socialization media [11].

\section{RESEARCH METHOD}

This study uses analytic observational method with a Cross sectional approach, in which the dependent and independent variables are measured in one time. The research was conducted in June-August 2018 at West Amanuban Sub-district Elementary Schools, South Central Timor District, East Nusa Tenggara Province. Stratified random sampling technique was used to determine the elementary school groups according to national test (NUN) results ranking: high and low. Afterwards, simple random sampling was used to determine study subjects of fifth grade students of each elementary school, thus determining 4 classes as study samples. This study used 107 students as samples, determined using purposive sampling technique. Inclusion criteria used were: fifth grade elementary school students of West Amanuban sub-district, 10-11 years old, no allergy to fruits and vegetables. Exclusion criteria used were: students absent or dropped out of school at the time span of the research. Data collected were parents' purchasing power which was measured by household's expenses, fruits and vegetables consumption, nutrition status, students' weight and height. Nutrition status was classified using IMT/U with Z-score as the determining standard of nutrition status. Data collected were analyzed using univariate and bivariate analyses. Bivariate analysis used Chi square test. Ethical approval and clearance wa obtained from the health research ethics committee of faculty of medicine, Sebelas Maret University. This research had already approved ethical clearance in registration number 104/UN27.6/KEPK/2018.

\section{RESULTS AND DISCUSSION}

The characteristics is presented in Table 1 of parents and children of the four West Amanuban sub-district elementary schools measured in this study were vocation, education; parents purchase power, and children fruits and vegetables consumption in regards to their nutrition status. According to Table 1, study subjects are 9-14 years old elementary school students and their parents. Subjects' characteristics show that 12 fathers work as civil-service employees (11.1\%), 23 fathers $(21.3 \%)$ as entrepreneurs, 73 fathers $(67.6 \%)$ as farmers, meanwhile for the mothers, 5 mothers $(4.6 \%)$ work as civil-service employees, 12 mothers $(11.1 \%)$ as entrepreneurs, 1 mother $(0.9 \%)$ as a farmer, and 90 mothers $(83.3 \%)$ as housewives. These results show that most of the students' parents work as farmers and housewives. According to [12], in America parents' ability to prepare meals for their children depends on their time availability. Parents' jobs influence their children's nutrition status, observed from meals consumed daily by a family. The higher the parents' vocational status, the more nutritious food is consumed by a family, on the contrary, the lower the parents' vocational status, the less nutritious food is consumed. According to [13], most parents work until late and that negatively influence their children's nutrition status.

Fathers' education levels are as follows: Elementary school 41 fathers $(38.0 \%)$, Junior high school 32 fathers (29.6\%), Senior high school 28 fathers (25.9\%), Diploma 3 fathers $(3.7 \%)$, Undergraduate 4 fathers $(3.7 \%)$, while the mothers: Elementary school 47 mothers (43.5\%), Junior high school 29 mothers (26.9\%), Senior high school 25 mothers (23.1\%), Diploma 3 mothers $(2.8 \%)$, Undergraduate 4 mothers (3.7\%). Most parents' education levels are elementary school. Parents' education influences their children's health and nutrition status, as mentioned in a study [14], in Pakistan. 
A father's education determines his income level, thus influences his family's health. On the other hand, a mother's education influences her parenting methods, which will determine her children's health. According to [3], in a study in a low income community, a mother's education has an enormous influence in a child's health, from early childhood to adulthood.

Table 1. Respondents characteristics

\begin{tabular}{|c|c|c|c|}
\hline Characteristics & $\mathrm{n}$ & $\%$ & $\overline{\mathrm{x}} \pm \mathrm{SD}$ \\
\hline$\overline{\text { Age }}$ & & & $11.14 \pm 0.942$ \\
\hline \multicolumn{4}{|l|}{ Father's vocation } \\
\hline Civil-service employee (PNS) & 12 & 11.1 & \\
\hline Entrepreneur & 23 & 21.3 & \\
\hline Farmer & 73 & 67.6 & \\
\hline Total & 108 & 100 & \\
\hline \multicolumn{4}{|l|}{ Mother's vocation } \\
\hline Civil-service employee (PNS) & 5 & 4.6 & \\
\hline Entrepreneur & 12 & 11.1 & \\
\hline Farmer & 1 & 0.9 & \\
\hline Housewife & 90 & 83.3 & \\
\hline Total & 108 & 100 & \\
\hline \multicolumn{4}{|l|}{ Father's education } \\
\hline Elementary school & 41 & 38.0 & \\
\hline Junior high school & 32 & 29.6 & \\
\hline Senior high school & 28 & 25.9 & \\
\hline Diploma & 3 & 3.7 & \\
\hline Undergraduate & 4 & 3.7 & \\
\hline Total & 108 & 100 & \\
\hline \multicolumn{4}{|l|}{ Mother's education } \\
\hline Elementary school & 47 & 43.5 & \\
\hline Junior high school & 29 & 26.9 & \\
\hline Senior high school & 25 & 23.1 & \\
\hline Diploma & 3 & 2.8 & \\
\hline Undergraduate & 4 & 3.7 & \\
\hline Total & 108 & 100 & \\
\hline \multicolumn{4}{|l|}{ Parent's purchasing power (IDR) } \\
\hline \multicolumn{4}{|l|}{ Very high: $>2,000,000 /$ month } \\
\hline \multicolumn{4}{|l|}{ High: $1,000,000 \mathrm{~s} / \mathrm{d}$} \\
\hline \multicolumn{4}{|l|}{$2,000,000 /$ month } \\
\hline $\begin{array}{l}\text { Medium: } 500,000 \mathrm{~s} / \mathrm{d} \\
1,000,000 / \text { month }\end{array}$ & 26 & 24.1 & \\
\hline Low $\leq 500,000 /$ month & 82 & 75.9 & \\
\hline Total & 108 & 100 & \\
\hline \multicolumn{4}{|l|}{ Fruits and vegetables consumption } \\
\hline Enough (fruits $\geq 2$, vegetables $\geq 3$ ) & 69 & 63.9 & \\
\hline Low (fruits<2, vegetables<3) & 39 & 36.1 & \\
\hline Total & 108 & 100 & \\
\hline
\end{tabular}

Medium purchasing power $(500,000-1,000,000) 26$ parents $(24.1 \%)$, low $(<500,000) 82$ parents (75.9\%). Research data show that parents' purchasing power in West Amanuban sub-district is low due to a very low income level. A person with low income level has a difficulty to obtain various food sources, for example fruits and vegetables, which are proven to reduce numerous chronic illnesses, such as heart disease, diabetes, and cancer. That research is in accordance to this study that shows very low parents' income levels in West Amanuban District, thus causing an inabilityto obtain various food sources that lowers children's nutrition status [15-16].

Children's fruits and vegetables consumption in West Amanuban sub-district are: enough (fruits $\geq 2$, vegetables $\geq 3$ ) 69 children (63.9\%) and low (fruits $<2$, vegetables $<3$ ) 39 children $(36.1 \%$ ). The data shows that the children have enough fruits and vegetables consumption, because most parents work as farmers, thus they plant fruits and vegetables for selling and also for consumption. Foods that are rich of fruits and vegetables have a positive effect to health. A few studies show a correlation between fruits and vegetables consumption and health. Some studies in children state that fruits and vegetables consumption can protect children from various diseases. These studies aim to alter children's behavior in consuming fruits and vegetables. Daily fruits and vegetables consumption is important because it affects children's immunity against diseases during their development to adulthood [17]. A study conducted to school students aged 13-15 years old tried to compare the frequency of energy food to fruits and vegetables consumption for 
breakfast. This study shows a higher frequency of energy food consumption to fruits and vegetables consumption for breakfast, and this behavioral pattern can negatively affect the children's health, not just during adolescence, but also into their adulthood [18-19]. The correlation between purchasing power, fruits and vegetables consumption, and elementary school students' nutrition status shown in Table 2.

Table 2. The correlation between purchasing power, fruits and vegetables consumption,

\begin{tabular}{cccccc}
\multicolumn{7}{c}{ and nutrition status } \\
\hline Variable & Very thin & Thin & normal & \multirow{2}{*}{ Total } & p-value \\
& & & & & 0.039 \\
Purchasing power & $3(13.6)$ & $4(18.2)$ & $15(68.2)$ & 22 & \\
Medium & $17(19.8)$ & $36(41.9)$ & $33(38.4)$ & 86 & \\
Low & & & & & 0.000 \\
Fruits and vegetables consumption & $12(17.4)$ & $9(13.0)$ & $48(69.6)$ & 69 & \\
Enough & $8(20.5)$ & $31(79.5)$ & $0(0)$ & 39 & \\
Low & 40 & 80 & 96 & & \\
Total & & & & &
\end{tabular}

Source: Primary data, 2018

Chi square test performed on these data shows a significant correlation between purchasing power and nutrition status $(\mathrm{p}=0.039)$ which means parents' purchasing power influences school children's nutrition status. According to the study performed in those four elementary schools, almost every student's parent's work as farmers and housewives, which causes a very low household purchasing power, and then results in very low children's food consumption which decreases the children's nutrition status. This result aligns with a study performed by [9] In America, low economic status can influence children's health. Economic conditions for example a low income level causes an inability to purchase household needs, thus influencing children's nutrition status [9, 20].

A family's economic condition is also influenced by parents', especially mother's, role in educating her children. Mother's knowledge is gained from her last education. An inability to fulfill a baby's nutritional need will influence his adult life [20-21]. A household with middle to lower economic condition tends to be vulnerable to food. Economic factors also influence a household's access to food sources. Parents' income influences a household's ability to access food sources $[5,30]$. A study in Chicago shows that the price of food highly influenced the community's purchasing power, and this fact led the government to lower the price of food for mothers and children, especially fruits and vegetables. This policy aims to give access to low income people to obtain nutritious food to increase children's nutrition status [22-23, 29]

Fruits and vegetables consumption and nutrition status $(\mathrm{p}=0.000)$. There is a correlation between fruits and vegetables consumption and nutrition status of school children in West Amanuban sub-district. Fruits and vegetables consumption is one of the indicators for balanced nutrition because fruits and vegetables are sources of vitamins, minerals, and fibers which act as antioxidants. The results of basic health research 2010 describe that fruits and vegetables consumption in the age group above 10 years old is still low: around $36.7 \%$ and $37.98 \%$. In Korea, the community's expenses to buy food supplies, such as vegetables, fruits, milk, and other food depend on parents' income level. Higher parents' income level leads to high expenses for food, while low income level leads to low consumption of fruits and vegetables. An adult's fruits and vegetables consumption behavior starts from their childhood and adolescence, and the facts are that children and adolescents do not fulfill WHO's standards of fruits and vegetables consumption, which is 400 grams per day [24-25]. Fruits and vegetables consumed without added fat or sugar contain low calorie, and are great sources of vitamin $\mathrm{C}$, beta-carotene, potassium, and fiber. The increase of fruits and vegetables consumption can decrease total calorie consumption and increase health quality, especially if fruits and vegetables are recommended as replacements for other fatty and sugary foods. Research suggests that higher fruits and vegetables consumption is also correlated to the decrease of sodium intake which is a risk factor for hypertension. Increasing fruits and vegetables consumption in children and pre-adolescents can decrease risks of overweight and obesity and other chronic diseases [19, 26-27].

Fruits and vegetables consumed without added fat and sugar are low in calorie, but able to provide vitamin $\mathrm{C}$, beta-carotene, potassium, and fiber. The increase of fruits and vegetables consumption can decrease total calorie consumption and increase health quality, especially when fruits and vegetables are consumed to substitute other more fatty and sugary foods. Research suggests that higher fruits and vegetables consumption also able to decrease sodium intake, which is a risk factor for hypertension. Increasing fruits and vegetables consumption in children and pre-adolescents can decrease risks of overweight and obesity and other chronic diseases [19, 26-27]. Fruits and vegetables consumption can improve a child's nutrition status, and also able to control overweight and underweight in children. Schools have an important role in increasing 
fruits and vegetables consumption in children. To fulfill children's needs of fruits and vegetables, schools can make these food sources more interesting to consume [28-29].

\section{CONCLUSION}

Study results show that there is a correlation between purchasing power, fruits and vegetables consumption, with nutrition status in elementary school students $(\mathrm{p}<0.05)$. Further studies concerning purchasing power, fruits and vegetables consumption, with nutrition status are needed.

\section{ACKNOWLEDGEMENTS}

The research was supported by Neonmat Presidental Instruction elementary school, Neonmat presidental instruction elementary school, GMIT Nulle elementary school, GMIT Nifukani elementary school, Directorate General of National Unity and Politics, department of education, parents, supervisors, and friends.

\section{REFERENCES}

[1] Tiwari, P.C and Joshi B. (2012), Natural and socio-economic factors affecting food security in the Himalayas, Food Sec., Vol. 4:195-207.

[2] Birhane, T., Shiferaw, S., Hagos, S and Mohindra, K. (2014). Urban food insecurity in the context of high food prices: a community based cross sectional study in Addis Ababa, Ethiopia, BMC Public Health, Vol. 14:680, $1471-2458 / 14 / 680$

[3] Abudayya A, Shi Z, Abed Y, Holmboe-ottesen G (2011). Diet, Nutritional Status and school performance Among Adolescents in Gaza Strip. Eastern mediterranean Health Journal, Vol. 17 . 3

[4] Hardiansyah, (2007), Review of determinan factors of food intake diversity. Fakulty of Human Ecology. Bogor Agricultur Institute. Nutrition and Dietetics Journal, Vol. 2(2), 55-74.

[5] Nagari, RK., Nindya., TS. (2017) .Energi sufficiency level, protein, and household food security status are correlated to nutrition status of children aged 6-8 years old, Amerta Nutr., Vol.189-197.

[6] Center of food consumption diversification and security board. (2015). Strategic plan of food consumption diversification and security board.

[7] Indonesian Republic Ministri of Health. (2014). Balanced nutrition guidelines. Jakarta, Indonesian Republic Ministri of Health.

[8] DeSmet, A ., Liu, Y., Bourdeaudhuij, D. I., Baranowski T and Thompson D. (2017). The effectiveness of asking behaviors among 9-11 year-old children in increasing home availability and children's intake of fruit and vegetables: results from the Squire's Quest II self-regulation game intervention. International Journal of Behavioral Nutrition and Physical Activity, Vol. 14:51,

[9] Tandon, P.J., Zhou, C., Sallis, J., Cain, LK., Frank, L., and Saelens, B. (2012). Home environment relationships with children's physical activity, sedentary time, and screen time by socioeconomic status. International Journal of Behavioral Nutrition and Physical Activity, 2012, Vol. 9:88

[10] Krølner, R, Rasmussen, M, Brug, J, Klepp, KI, Wind, M., Due, P. (2011). Determinants of fruit and vegetable consumption among children and adolescents: a review of the literature. Part II: qualitative studies International Journal of Behavioral Nutrition and Physical Activity.Vol. 8:112.

[11] Mohammad A, and Madanijah S. (2015). Fruits adn vegetables consumption of elementary school student in Bogor. Food Nutrition Journal. Vol. 10(1): 71-76 ISSN 1978-1059.

[12] Bauer, K., Hearst, M., Escoto, K., Berge, J., Neumark-Sztainer, D.(2012). Parental employment and work-family stress: Associations with family food environments, Social Science \& Medicine.Vol. 75. 496e504

[13] Kelly, E. L., Moen, P., \& Tranby, E. (2011). Changing workplaces to reduce workfamily conflict: schedule control in a white-Collar Organization. American Sociological Review, Vol. 76, 265e290.

[14] Aslam, M And Kingdon, G . (2012). Parental Education and Child Health-Understanding the Pathways of Impact in Pakistan. World Development. Vol. 40, No. 10, pp. 2014-2032, 2012.

[15] Haynes-Maslow, L., Auvergne, L., Mark, B., Ammerman, A, and Weiner, B. (2016). Low-income individuals' perceptions about fruit and vegetable access programs: A qualitative study. J Nutr Educ Behav. 2015 ; Vol. 47(4): 317-324.e1. doi:10.1016/j.jneb.2015.03.005.

[16] Abusabha R, Namjoshi D, Klein A. (2011). Increasing access and affordability of produce improves perceived consumption of vegetables in low-income seniors. J Am Diet Assoc. Vol. 111:1549-55.

[17] Pearson, N., Atkin, AJ., Biddle, S., Gorely, T. (2008). Family Correlates Of Fruit and Vegetable Consumption in Chlidren and Adoslence: A Systematic Review. Public Health Nutrition. Vol. 12(2) : 267-283.

[18] Lazzeri G, Pammolli A, Azzolini E, Simi R, Meoni V, de Wet DR, \& Giacchi MV. (2013) Association between fruits and vegetables intake and frequency of breakfast and snacks consumption: a cross study. Nutrition Journal, Vol. 12, 123. 
[19] Boeing H, Bechthold A, Bub A, Ellinger S, Haller D, Kroke A, Leschik-Bonnet E, Müller MJ, Oberritter H, Schulze M, Stehle P, Watzl B. (2012).vegetables and fruit in the prevention of chronic diseases. Eur. J. Nutr 2012, Vol. 51(6):637-63.

[20] Cesare, M., Bhatti, Z., Soofi, S., Fortunato, L., Ezzati, M., and Bhutta, Z. (2015). Geographical and socioeconomic inequalities in women and children's nutritional status in Pakistan in 2011: an analysis of data from a nationally representative survey. Lancet Glob Health. Vol. 3: e229-39

[21] Martorell, R., Horta, B., Adair, L., Stein, A., Richter, L., Fall, C., Bhargava, S., Biswas., K and Perez, L. (2010). Weight gain in the first two years of life is an important predictor of schooling outcomes in pooled analyses from five birth cohorts from low- and middle-income countries. J. Nutr. Vol. 140: 348-354.

[22] Zenk, S.,, Powell, L., Rimkus, L., Isgor, Z.,Barker, D., Ohri-Vachaspati, P., and Chaloupka,F. (2015). Relative and Absolute Availability of Healthier Food and Beverage Alternatives Across Communitiesin the United States. American Journal of Public Health. Vol 104, No. 11

[23] Andreyeva, T., Long, MW., Brownell, KD. (2010).The impact of food prices on consumption: A systematic review of research on the price elasticity of demand for food. Am J Public Health. Vol.100(2):216-222. [PubMed: 20019319].

[24] Baek,Y.J., Paik, H.Y. and Shim, E.J. (2014). Association between family structure and food group intake in children. The Korean Nutrition Society and the Korean Society of Community Nutrition. Nutrition Research and Practice. Vol. 8(4):463-468.

[25] Dwi, Y., Irwanto and Wibowo, A. (2016). The Relationship between Nutritional Status and Learning Achievement of School-Age Children in Elementary School. Dama International Journal of Researchers (DIJR), ISSN: 2343-6743, Vol.1(7), pp. 1-4.

[26] Thompson, D., Ferry,R., Cullen, K, and Liu, Y. (2016). Improvement in fruit and vegetable consumption associated with more favorable energy density, nutrient, and food group intake, but not kilocalories. J Acad Nutr Diet. 2016 September ;Vol. 116(9): 1443-1449. doi:10.1016/j.jand.2016.05.002.

[27] Vernarelli JA, Mitchell DC, Hartman TJ, Rolls BJ. (2011) Dietary energy density is associated with body weight status and vegetable intake in U.S. children. J. Nutr., 2011; Vol. 141(12):2204-2210.

[28] Kim, S., Moore, L., Galuska, D., Wright, P., Harris, D., Grummer-Strawn, L., Merlo, C., Nihiser, A., Rhodes,D.(2014).Vital Signs: Fruit and Vegetable Intake Among Children - United States, 2003-2010. Morbidity and Mortality Weekly Report. August 8, 2014. Vol. 63.No. 31

[29] Blanchette L, Brug J.(2009). Determinants of fruit and vegetable consumption among 6-12-year-old children and effective interventions to increase consumption, J.Hum.Nutr.Diet., Vol.18:431-43.

[30] O’Connor MT., Hughes, S., Watson, K., Baranowski, T., Nicklas, T., Fisher, J., Beltran, A., Baranowski, J., Qu, H., Shewchuk, R (2009).Parenting practices are associated with fruit and vegetable consumption in pre school children, Public Health Nutrition, Vol. 13(1), 91-101. 